\title{
ЗМІНИ АНТИОКСИДАНТНОЇ СИСТЕМИ ТА ПЕРОКСИДНОГО ОКИСНЕННЯ ЛІПІДІВ У КАМЕРАХ СЕРЦЯ ЗА УМОВ ПОСТРЕЗЕКЦІЙНОЇ ПОРТАЛЬНОЇ ГІПЕРТЕНЗІЇ
}

Вступ. Пострезекційна портальна гіпертензія призводить до гемодинамічних змін і структурноі перебудови судин та органів басейну ворітної печінкової вени, а також ремоделювання структур серця, які при цьому вивчено недостатньо.

Мета дослідження - вивчити особливості змін антиоксидантної системи, пероксидного окиснення ліпідів, структур камер серця за умов пострезекційної портальної гіпертензії.

Методи дослідження. Біохімічними та морфологічними методами вивчено зміни антиоксидантної системи, пероксидного окиснення ліпідів, структур камер серця 40 лабораторних статевозрілих білих щурів-самців, яких було поділено на 2 групи: 1-ша (контрольна) нараховувала 20 інтактних тварин, 2-га 20 щурів після видалення лівої і правої бокових часток печінки (58,1%). Евтаназію тварин здійснювали шляхом кровопускання за умов тіопентал-натрієвого наркозу через 1 місяць від початку експерименту. 3 камер серця виготовляли гістологічні мікропрепарати, на яких гістостереометрично визначали стромально-паренхіматозні відношення, відносні об'єми пошкоджених кардіоміоцитів та ендотеліоцитів. Кількісні величини обробляли статистично.

Результати й обговорення. Встановлено, що видалення лівої і правої бокових часток печінки в білих щурів призводить до пострезекційної портальної гіпертензії, виражених змін показників антиоксидантної системи, пероксидного окиснення ліпідів та структур міокарда. Найбільш виражені морфологічні зміни виявлено у лівому шлуночку та лівому передсерді.

Висновки. Видалення лівої і правої часток печінки в білих щурів призводить до пострезекційної портальної гіпертензії, погіршення антиоксидантного захисту організму, морорологічних змін структур камер серця, підвищення в них концентрації продуктів ліпопероксидації, які корелюють із стромально-паренхіматозними відношеннями, відносними об'ємами пошкоджених кардіоміоцитів та ендотеліоцитів. Домінують морофрологічні зміни у лівому шлуночку та лівому передсерді.

КЛЮЧОВІ СЛОВА: пострезекційна портальна гіпертензія; камери серця; ліпопероксидація; антиоксидантна система.

ВСТУП. Відомо, що резекцію печінки на сьогодні нерідко виконують у хірургічних клініках. Показаннями до цієї операції $€$ доброякісні та злоякісні пухлини, метастази, травми печінки, внутрішньопечінковий холангіолітіаз, альвеолярний ехінококоз, трансплантація печінки $[1,2]$. Резекція великих об'ємів печінки може спричиняти пострезекційну портальну гіпертензію, для якої характерні кровотечі з варикозно розширених вен стравоходу, шлунка, прямої кишки, асцит, спленомегалія, вторинний гіперспленізм, паренхіматозна жовтяниця, портосистемна енцефалопатія, печінкова недостатність, гепаторенальний синдром, поліорганна недостатність [3-5]. Пострезекційна портальна гіпертензія призводить до гемодинаміних змін і структурної перебудови судин та органів басейну ворітної печін-

(с М. С. Гнатюк, Л. В. Татарчук, Н. М. Гданська, Н. Я. Монастирська, 2020. кової вени, а також ремоделювання структур серця, які при цьому вивчено недостатньо [3-5].

Мета дослідження - вивчити особливості змін антиоксидантної системи, пероксидного окиснення ліпідів, структур камер серця за умов пострезекційної портальної гіпертензії.

МЕТОДИ ДОСЛІДЖЕННЯ. КомпЛексом біохімічних та морфологічних методів вивчено зміни антиоксидантної системи, пероксидного окиснення ліпідів, структур камер серця 40 лабораторних статевозрілих білих щурів-самців, які було поділено на 2 групи: 1-ша (контрольна) нараховувала 20 інтактних тварин, 2-га - 20 щурів після видалення лівої і правої бокових часток печінки (58,1 \% її паренхіми) [5]. Евтаназію тварин здійснювали шляхом кровопускання за умов тіопентал-натрієвого наркозу через 1 місяць від початку експерименту. В крові експерименталь- 
них тварин визначали параметри, які характеризували стан антиоксидантного захисту: активність супероксиддисмутази (СОД), каталази (КТ), церулоплазміну (ЦП) [6]. Вирізані шматочки камер серця фріксували в 10 \% нейтральному розчині формаліну, проводили через етилові спирти зростаючої концентрації та поміщали у парафрін. Мікротомні зрізи товщиною 5-6 мкм після депарафрінізації забарвлювали гематоксилін-еозином, за Ван-Гізон, Маллорі, Вейгертом, толуїдиновим синім [7]. Морфометрично в камерах серця визначали стромально-кардіоміоцитарні відношення (СКМВ), відносні об'єми пошкоджених кардіоміоцитів (ВОПКМ) та ендотеліоцитів (ВОПЕн) лівого (ЛШ) і правого (ПШ) шлуночків, лівого (ЛП) та правого (ПП) передсердь [8]. Моророметрію досліджуваних структур камер серця проводили за допомогою світлового мікроскопа Olimpus BX-23 із цифрровою відеокамерою і пакетом прикладних програм "Відео-тест 5,0" та "Відео-розмір 5,0". У гомогенатах камер серця також визначали вміст дієнових кон'югатів (ДК) і активних продуктів тіобарбітурової кислоти (ТБК-АП). Вміст ДК визначали за здатністю до інтенсивного поглинання кон'югованих дієнових структур гідропероксидів ліпідів у діапазоні 232-234 нм, вміст ТБК-АП - за методом, що ґрунтується на здатності взаємодіяти в кислому середовищі з тіобарбітуровою кислотою [9]. Проводили кореляційний аналіз між показниками пероксидного окиснення ліпідів, антиоксидантної системи та морфометричними параметрами камер серця з визначенням коефіцієнта парної кореляції (r). Силу кореляційних зв'язків оцінювали за чотирма ступенями: сильним $(r=0,7-0,9)$, значним $(r=0,5-0,7)$, помірним $(r=0,3-0,5)$, слабким $(r<0,3)$ [8]. Отримані кількісні показники обробляли статистично. Обробку отриманих результатів виконано у відділі системних статистичних досліджень Тернопільського національного медичного університету імені І. Я. Горбачевського МОЗ України в програмному пакеті STATISTICA. Різницю між порівнюваними величинами визначали за критеріями Стьюден- та і Манна - Уїтні $[8,10]$. Експерименти й евтаназію щурів проводили з дотриманням Загальних етичних принципів експериментів на тваринах, ухвалених на Першому національному конгресі з біоетики (Київ, 2001), відповідно до Європейської конвенції про захист хребетних тварин, що використовуються для дослідних та інших наукових цілей, а також Закону України "Про захист тварин від жорстокого поводження" (від 21.02.2006 р.).

РЕЗУЛЬТАТИ Й ОБГОВОРЕННЯ. РезеКЦіЯ лівої і правої бокових часток печінки $(58,1 \%$ її паренхіми) призводила до розвитку пострезекційної портальної гіпертензії, що підтверджувалося розширенням та повнокров'ям ворітної печінкової вени, брижових вен, а також вен тонкої і товстої кишок, спленомегалією, асцитом [3, 4].

Результати дослідження вмісту ДК і ТБК-АП у камерах серця експериментальних тварин при пострезекційній портальній гіпертензії наведено в таблиці 1. Після всестороннього аналізу цих даних встановлено, що у шлуночках і передсердях серцевого м'яза суттєво посилилися процеси ліпопероксидації. Так, у лівому шлуночку за умов змодельованої патології концентрація ДК статистично достовірно ( $<<0,001)$ збільшилася майже в 3,4 раза, у правому - в 3,1, у лівому передсерді - в 3,3, у правому - в 1,4. Отримані дані свідчать про те, що активність ліпопероксидації в камерах серця при пострезекційній портальній гіпертензії суттєво зростала. Найвираженіші зміни досліджуваного показника при цьому виявлено у лівому шлуночку та лівому передсерді.

Аналіз концентрації ТБК-АП у гомогенатах камер серця у змодельованих експериментальних умовах показав високу активність утворення продуктів пероксидного окиснення ліпідів. При цьому в лівому шлуночку їх вміст з вираженою статистично достовірною різницею $(p<0,001)$ збільшився в 5,4 раза, а у правому - в 4,3 раза. У гомогенатах передсердь концентрація ТБК-АП змінювалась аналогічно. Так, у лівому перед-

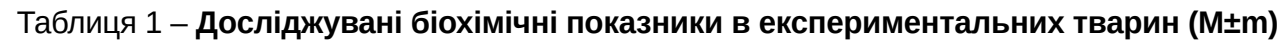

\begin{tabular}{|c|c|c|c|}
\hline \multirow{2}{*}{ Показник } & \multirow{2}{*}{ Камера серця } & \multicolumn{2}{|c|}{ ГГрупа спостереження } \\
\hline & & 1-ша & 2-га \\
\hline \multirow[t]{4}{*}{ ДК, ум. од./г } & ЛШ & $1,160 \pm 0,030$ & $3,900 \pm 0,090^{\star \star \star \star}$ \\
\hline & ПШ & $1,150 \pm 0,030$ & 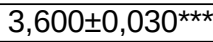 \\
\hline & ЛП & $1,120 \pm 0,020$ & $3,700 \pm 0,020^{\star \star \star}$ \\
\hline & ПП & $1,100 \pm 0,020$ & $2,880 \pm 0,020$ *** \\
\hline \multirow[t]{4}{*}{ ТБК-АП, мКмоль/кГ } & ЛШ & $0,630 \pm 0,015$ & $3,400 \pm 0,030^{\star \star \star}$ \\
\hline & ПШ & $0,674 \pm 0,012$ & $2,900 \pm 0,030^{\star \star \star}$ \\
\hline & ЛП & $0,620 \pm 0,012$ & $3,100 \pm 0,030^{\star \star \star *}$ \\
\hline & ПП & $0,620 \pm 0,012$ & $2,860 \pm 0,030^{\star \star \star}$ \\
\hline
\end{tabular}

Примітка. Тут і в таблиці 3: ** - p<0,001 порівняно з 1-ю групою. 
серді вона статистично достовірно $(\mathrm{p}<0,001)$ при пострезекційній портальній гіпертензії збільшилася в 5,1 раза, у правому - в 4,6 раза. Це свідчило про те, що за умов пострезекційної портальної гіпертензії в камерах серця суттєво посилювалися процеси ліпопероксидації, що вказувало на високу активність мембраноруйнівних процесів [9], які домінували у лівому шлуночку та лівому передсерді.

Показники, що характеризували стан антиоксидантної системи експериментальних тварин, при пострезекційній портальній гіпертензії також змінювалися (табл. 2). Так, активність СОД при цьому статистично достовірно ( $<<0,001)$ зменшилася на 15,5 \%, КАТ - на 25,6 \%, ЦП - на 14,0 \%, що свідчило про зниження антиоксидантного захисту організму [6].

Досліджувані кардіопараметри камер серця лабораторних статевозрілих білих щурів-самців показано в таблиці 3. Після аналізу наведених даних встановлено, що отримані кількісні морфологічні параметри тварин при портальній гіпертензії змінювалися порівняно з контрольними величинами. Так, стромально-паренхіматозні відношення у лівому шлуночку 3 вираженою статистично достовірною різницею $(p<0,001)$ збільшилися в 1,6 раза, що вказувало на зростання кількості стромальних структур у цій камері серця. Даний моророметричний параметр у правому шлуночку збільшився на 27,7 \% ( $<<0,001)$, у лівому передсерді - на 35,4 \%, у правому - майже на 16,0 \% ( $<<0,001)$.

Відносний об'єм пошкоджених кардіоміоцитів у лівому шлуночку за умов змодельованої патології статистично достовірно ( $<<0,001)$ зріс із $(2,90 \pm 0,06)$ до $(36,30 \pm 0,24) \%$, тобто у 12,5 раза, у правому - в 8,1 раза, у лівому передсерді - в $9,6$ раза, у правому - в 7,3 раза ( $p<0,001)$. Аналогічно змінювався відносний об'єм пошкоджених ендотеліоцитів судинного русла камер серця при пострезекційній портальній гіпертензії. Так, у лівому шлуночку цей кардіопараметр з вираженою статистично достовірною різницею $(p<0,001)$ збільшився $3(2,10 \pm 0,04)$ до $(22,10 \pm 0,18) \%$, тобто в 10,5 раза, у правому - в 7,6 раза, у лівому передсерді-у 8,2 раза, у правому - в 5,8 раза $(p<0,001)$.

Отримані та проаналізовані гістостереометричні показники найбільш виражено змінювались у лівому шлуночку і лівому передсерді, що підтверджувалося динамікою стромально-паренхіматозних відношень, а також відносними об'ємами пошкоджених кардіоміоцитів та ендотеліоцитів. Венозне повнокров'я та гіпертензія в системі ворітної печінкової вени призводять не тільки до структурної перебудови вен у портальній системі, але й до морфологічних змін у артеріях. Останні характеризуються потовщенням стінки, спазмом, звуженням просвіту, що супроводжується посиленою роботою лівого шлуночка та морсоологічними змінами в ньому.

Під час кореляційного аналізу виявлено наявність взаємозв'язків між показниками пероксидного окиснення ліпідів, антиоксидантного захисту і досліджуваними кардіопараметрами. Встановлено наявність сильних позитивних кореляційних взаємозв'язків між рівнями ДК, ТБК-АП та гістостереометричними параметрами

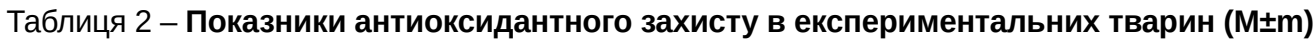

\begin{tabular}{||l|c|c||}
\hline \multicolumn{1}{|c|}{ Показник } & \multicolumn{2}{|c|}{ Група спостереження } \\
\cline { 2 - 3 } & 1-ша & 2 -га \\
\hline СОД, ум. оД./мЛ & $2,960 \pm 0,030$ & $2,500 \pm 0,020^{\star \star \star}$ \\
\hline КАТ, мкат/л & $0,148 \pm 0,020$ & $0,110 \pm 0,001^{\star \star \star}$ \\
\hline ЦП, мг/л & $86,400 \pm 1,800$ & $74,300 \pm 1,500^{\star \star}$ \\
\hline
\end{tabular}

Примітка. ** - p<0,01; *** - p<0,001 порівняно з 1-ю групою

Таблиця 3 - Досліджувані кардіопараметри в експериментальних тварин (M士m)

\begin{tabular}{|c|c|c|}
\hline \multirow{2}{*}{ Параметр } & \multicolumn{2}{|c|}{ Гррупа спостереження } \\
\hline & 1-ша & 2-га \\
\hline СКМВ ЛШ & $0,175 \pm 0,002$ & $0,280 \pm 0,003^{\star \star \star}$ \\
\hline ВОПКМ ЛШ, \% & $2,900 \pm 0,060$ & 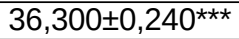 \\
\hline ВОПЕн ЛШ, \% & $2,100 \pm 0,040$ & $22,100 \pm 0,180^{\star \star \star}$ \\
\hline CКMB ПШ & $0,184 \pm 0,002$ & $0,235 \pm 0,003^{\star \star \star}$ \\
\hline ВОПКМ ПШ, \% & $2,700 \pm 0,040$ & 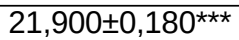 \\
\hline ВОПКМ ЛП, \% & $2,300 \pm 0,060$ & 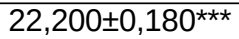 \\
\hline ВОПЕн ЛП, \% & $2,250 \pm 0,030$ & $18,450 \pm 0,120^{\star \star \star}$ \\
\hline СКМВ ПП & $0,194 \pm 0,002$ & $0,225 \pm 0,002^{\star \star \star}$ \\
\hline ВОПКМ ПП, \% & $2,200 \pm 0,020$ & $16,100 \pm 0,120^{\star \star \star}$ \\
\hline
\end{tabular}


$(\mathrm{r}=+0,78 \div+0,85)$. Досліджувані взаємозв'язки найбільш вираженими були між ДК і ВОПКМ ЛШ $(r=+0,86 \pm 0,04)$ та між ТБК-АП і ВОПКМ ЛШ $(\mathrm{r}=+0,82 \pm 0,03)$. Між досліджуваними кардіопараметрами і СОД, КАТ, ЦП існували помірні негативні кореляційні взаємозв'язки, які коливалися від -0,46 до -0,50. Наведене вказує на те, що виявлені зміни показників антиоксидантної системи пов'язані не тільки зі структурними змінами в камерах серця, але і з пошкодженнями органів портальної системи, які мають місце при пострезекційній портальній гіпертензії.

Як показали результати світлооптичного дослідження гістологічних мікропрепаратів камер серця, при пострезекційній портальній гіпертензії в них відбувалися виражені структурні зміни. При цьому відмічали виражене розширення та повнокров'я венозних судин камер серця, нерівномірність та деформацію їх просвіту. Спостерігали також перивазальний набряк, який місцями звужував та деформував досліджувані судини. Проявлялися дистрофрія ендотеліоцитів та, місцями, десквамація останніх. Деякі ендотеліоцити - з явищами набряку, межі між ними не чіткі, частина вказаних клітин дистрофрічно та некробіотично змінена. Розміри кардіоміоцитів та їх ядер збільшені, спостерігали осередки їх набряку, дистрофрії і некробіозу. Відмічали набряк

\section{СПИСОК ЛІТЕРАТУРИ}

1. Особливості виконання обширних резекцій печінки з урахуванням профрілактики післяопераційних ускладнень / І. В. Волченко, В.М.Лихман, Д. І. Скорий, А. М. Шевченко // Харківська хірургічна школа. 2016. - № 3 (78). - С. 35-39.

2. Хірургічне лікування вогнищевого ураження печінки: аналіз результатів та перспективи / О. І. Дронов, С. В. Земсков, Ю. П. Бакунець, П. П. Бакунець // Клініч. хірургія. - 2016. - № 1. - С. 28-31.

3. Дзигал О. Ф. Формування полісиндромної недостатності хворих на цироз печінки 3 портальною гіпертензією / О. Ф. Дзигал // Вісн. наук. дослідж. 2017. - № 2. - С. 88-92.

4. Гарбузенко Д. В. Морфофункциональная перестройка печеночного сосудистого русла в патогенезе портальной гипертензии при циррозе печени / Д. В. Гарбузенко // Тер. арх. - 2014. - № 86 (2). C. 90-95.

5. Гнатюк М. С. Морфометрична оцінка особливостей ремоделювання структур дванадцятипалої кишки при резекції різних об'ємів печінки / М. С. Гнатюк, Л. В. Татарчук, О. Б. Ясіновський // Наук. вісн. Ужгород. ун-ту. Серія "Медицина". - 2016. Вип. 1 (53). - С. 92-95. строми, її розростання і вогнищеві стромальні гістіоцитарні інфрільтрати. Розширення венозних судин, переповнення їх фрорменими елементами крові, явища стазів, тромбозів свідчили про виражене порушення їх дренажної функції. Венозний застій у досліджуваних судинах призводив до посилення гіпоксії, дистрофрії та некрозів ендотеліоцитів, кардіоміоцитів, стромальних структур, інфільтративних і склеротичних процесів.

ВИСНОВКИ. Видалення лівої і правої бокових часток печінки в білих щурів призводить до пострезекційної портальної гіпертензії, погіршення антиоксидантного захисту організму, морфологічних змін структур камер серця, підвищення в них концентрації продуктів ліпопероксидації, які корелюють із стромально-паренхіматозними відношеннями, відносними об'ємами пошкоджених кардіоміоцитів та ендотеліоцитів. Домінують морфологічні зміни у лівому шлуночку та лівому передсерді.

Перспективи подальших досліджень. Детальне всестороннє вивчення змін антиоксидантної системи, пероксидного окиснення ліпідів і структурно-фрункціональних змін серця при пострезекційній портальній гіпертензії дозволить істотно розширити своєчасну діагностику, корекцію та профрілактику досліджуваної патології.

6. Флекей Н. В. Стан антиоксидантної системи в білих щурів при введенні кадмію на тлі споживання питної води з різними концентраціями іонів натрію / Н. В. Флекей // Мед. та клініч. хімія. - 2015. - 17, № 2 (63). - С. 84-86.

7. Горальський Л. П. Основи гістологічної техніки і морфосрункціональні методи досліджень у нормі і при патології / Л. П. Горальський, В. Т. Хомич, О. І. Кононський. - Житомир : Полісся, 2011. - 288 с.

8. Автандилов Г. Г. Основы количественной патологии / Г. Г. Автандилов. - М. : Медицина, 2002. $240 \mathrm{c}$.

9. Новые люминесцентные методы оценки окислительного стресса у больных с системными васкулитами /Е. В. Проскурнина, А. Е. Шеримова, П. М. Полимова, М. М. Созарукова // Технологии живых систем. - 2016. - № 13 (8). - С. 26-36.

10. Гржибовский А. И. Сравнение количественных данных двух парных выборок с использованием программного обеспечения Statistica и SPSS: параметрические и непараметрические критерии / А. И. Гржибовский, О. В. Иванов, М. А. Горбатова // Наука и здравоохранение. - 2016. - 3. - С. 5-25. 


\section{REFERENCES}

1. Volchenko, I.V., Lykhman, V.M., Skoryy, D.I., \& Shevchenko, A.M. (2016). Osoblyvosti vykonannia obshyrnykh rezektsii pechinky z urakhuvanniam profilaktyky pisliaoperatsiinykh uskladnen [Peculiarities of performing extensive liver resections taking into account the prevention of postoperative complications]. Kharkivska khirurhichna shkola - Kharkiv Surgical School, 3 (78), 35-39 [in Ukrainian].

2. Dronov, O.I., Zemskov, S.V., Bakunets, Y.P., \& Bakunets, P.P. (2016). Khirurgicheskoye lecheniye ochagovogo porazheniya pecheni analiz rezultatov i perspektivy [Surgical treatment of focal liver disease: analysis of results and prospects]. Klinicheskaya khirurgiya Clinical Surgery, 1, 28-31 [in Russian].

3. Dzyhal, O.F. (2017). Formuvannia polisyndromnoi nedostatnosti khvorykh na tsyroz pechinky z portalnoiu hipertenziieiu [Formation of polysyndromic insufficiency of patients with liver cirrhosis with portal hypertension]. Visnyk naukovykh doslidzhen - Bulletin of Scientific Research, 2, 88-92 [in Ukrainian].

4. Garbuzenko, D.V. (2014). Morfofunktsionalnaya perestroyka pechenochnogo sosudistogo rusla $v$ patogeneze portalnoy gipertenzii pri tsirroze pecheni [Morphofunctional rearrangement of the hepatic vasculature in the pathogenesis of portal hypertension in liver cirrhosis]. Ter. Arkh. - Ter.Arch., 86 (2), 90-95 [in Russian].

5. Hnatiuk, M.S., Tatarchuk, L.V., \& Jasinovskyy, O.B. (2016). Morfometrychna otsinka osoblyvostei remodeliuvannia struktur dvanadtsiatypaloi kyshky pry resektsii riznykh obiemiv pechinky [Morphometric evaluation of the features of remodeling of duodenal structures during resection of different volumes of the liver]. Naukovyi visnyk Uzhhorodskoho universytetu. Seriia "Medytsyna"Scientific Herald of Uzhhorod University. Series "Medicine", 1 (49), 3-5 [in Ukrainian].
6. Flekey, N.V. (2015). Stan antyoksydantnoi systemy $v$ bilykh shchuriv pry vvedenni kadmiiu na tli spozhyvannia pytnoi vody z riznymy kontsentratsiiamy ioniv natriiu [The state of the antioxidant system in white rats with the introduction of cadmium on the background of drinking water consumption with different concentrations of sodium ions]. Medychna ta klinichna khimiia - Medical and Clinical Chemistry, 2 (63), 84-86 [in Ukrainian].

7. Goralsky, L.P., Khomich, V.T., \& Kononsky, O.I. (2011). Osnovy histolohichnoi tekhniky i morfofunktsionalni metody doslidzhen u normi i pry patolohii [Fundamentals of histological technique and morphofunctional research methods in normal and in pathology]. Zhytomyr: Polissia [in Ukrainian].

8. Avtadnilov, G.G. (2002). Osnovy kolichestvennoy patologicheskoy anatomii [Basis of quantitative pathological anatomy]. Moscow: Meditsyna [in Russian].

9. Proskurnina, E.V., Sherimova, A.E., Polimova, P.M., \& Sozarukova, M.M. (2016). Novi luminestsentni metody otsenky okyslitelnogo stresa u bolnykh s systemnymy vaskulitamy [New luminescent methods for assessing oxidative stress in patients with systemic vasculitis]. Tekhnologii zhyvykh system - Technologies of Living Systems, 13 (8), 26-36 [in Russian].

10. Grzhibovskiy, A.I., Ivanov, O.V., \& Gorbatova, M.A. (2016). Sravneniye kolichestvennykh dannykh dvukh parnykh vyborok s vnedreniyem programmnogo obespecheniya Statistica i SPSS: parametricheskiye i neparametricheskiye kriterii [Comparison of quantitative data of two paired samples using Statistica and SPSS software: parametric and nonparametric criteria]. Nauka $i$ zdravookhraneniye - Science and Health, 3, 5-25 [in Russian].

М. С. Гнатюк, Л. В. Татарчук, Н. Н. Гданская, Н. Я. Монастырская ТЕРНОПОЛЬСКИЙ НАЦИОНАЛЬНЫЙ МЕДИЦИНСКИЙ УНИВЕРСИТЕТ ИМЕНИ И. Я. ГОРБАЧЕВСКОГО МОЗ УКРАИНЫ

\section{ИЗМЕНЕНИЯ АНТИОКСИДАНТНОЙ СИСТЕМЫ И ПЕРЕКИСНОГО ОКИСЛЕНИЯ ЛИПИДОВ В КАМЕРАХ СЕРДЦА В УСЛОВИЯХ ПОСТРЕЗЕКЦИОННОЙ ПОРТАЛЬНОЙ ГИПЕРТЕНЗИИ}

\section{Резюме}

Вступление. Пострезекционная портальная гипертензия приводит к гемодинамическим изменениям и структурной перестройке сосудов и органов бассейна воротной печеночной вены, а также ремоделированию структур сердца, которые при этом изучены недостаточно.

Цель исследования - изучить особенности изменений антиоксидантной системы, перекисного окисления липидов, структур камер сердца в условиях пострезекционной портальной гипертензии.

Методы исследования. Биохимическими и морфологическими методами изучены изменения антиоксидантной системы, перекисного окисления липидов, структур камер сердца 40 лабораторных половозрелых белых крыс-самцов, которые были разделены на 2 группы: 1-я (контрольная) насчитывала 20 интактных животных, 2-я - 20 крыс после удаления левой и правой боковых долей печени (58,1 \%). Эвтаназию животных осуществляли путем кровопускания в условиях тиопентал-натриевого наркоза через 1 месяц после начала эксперимента. Из камер сердца изготавливали гистологические микропрепараты, на которых гистостереометрически определяли стромально-паренхиматозные отношения, 
относительные объемы поврежденных кардиомиоцитов и эндотелиоцитов. Количественные показатели обрабатывали статистически.

Результаты и обсуждение. Установлено, что удаление левой и правой боковых долей печени у белых крыс приводит к пострезекционной портальной гипертензии, выраженным изменениям показателей антиоксидантной системы, перекисного окисления липидов и структур миокарда. Наиболее выраженные морфологические изменения выявлены в левом желудочке и левом предсердии.

Выводы. Удаление левой и правой боковых долей печени у белых крыс приводит к пострезекционной портальной гипертензии, ухудшению антиоксидантной защиты организма, морфологическим изменениям структур камер сердца, повышению в них концентрации продуктов липопероксидации, которые коррелируют со стромально-паренхиматозными отношениями, относительными объемами поврежденных кардиомиоцитов и эндотелиоцитов. Доминируют морофрологические изменения в левом желудочке и левом предсердии.

КЛЮЧЕВЫЕ СЛОВА: пострезекционная портальная гипертензия; камеры сердца; липопероксидация; антиоксидантная система.

M. S. Hnatjuk, L. V. Tatarchuk, N. M. Gdanska, N. Ja. Monastyrska I. HORBACHEVSKY TERNOPIL NATIONAL MEDICAL UNIVERSITY

\section{CHANGES OF ANTIOXIDANT SYSTEM AND LIPID PEROXIDATION IN HEART CHAMBERS IN CONDITIONS OF POSTRESECTION PORTAL HYPERTENSION}

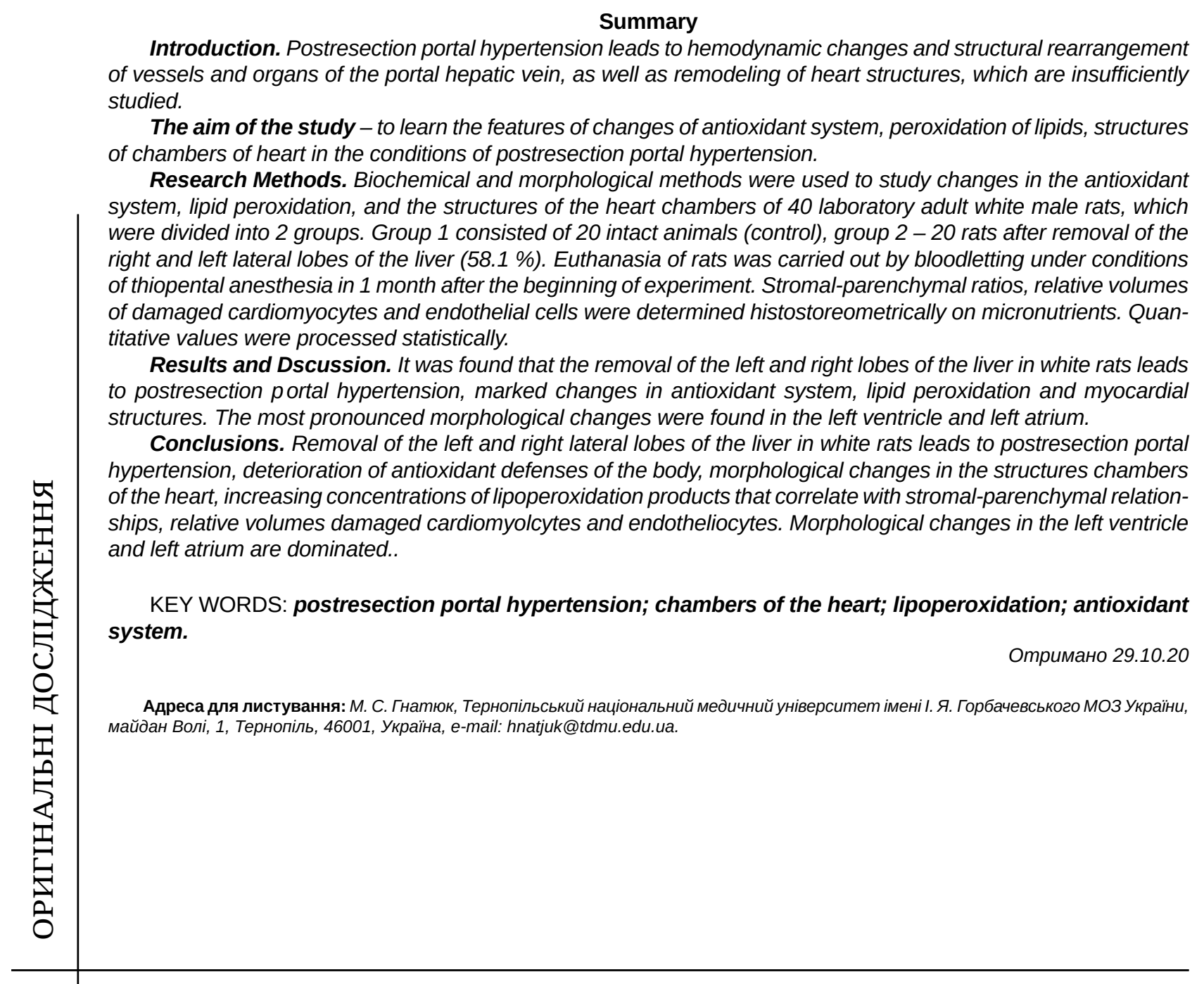

